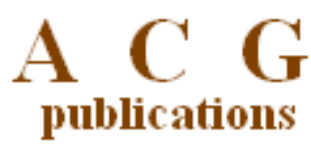

J. Chem. Metrol. 11-1 (2017) 23-30

journal of chemical metrology

\title{
Heavy metal determination of unfertilised vegetables and univariate analysis of the results
}

\author{
Mustafa Sahin Dundar ${ }^{*}$, Huseyin Altundag and Aysenur Yılmaz \\ Sakarya University, Faculty of Arts and Sciences, Department of Chemistry, 54187, \\ Sakarya, Türkiye
}

(Received February, 13; 2017; Revised March 8, 2017; Accepted March 13, 2017)

\begin{abstract}
Heavy metal contamination in water and food samples is thought as the result of human activities such as agriculture, traffic and industrial process in this century. Trace metal contents in the soil have increased with the contributions of both industrial and agricultural operations. Chemical fertilizers cause unbalance of the food in the soil. When these facts considered heavy metal accumulation in the vegetables may be occurred because of the over fertilization. In recent years interest on vegetables that fertilization is not applied has increased. In this study some heavy metal contents such as $\mathrm{Cu}, \mathrm{Fe}, \mathrm{Mn}, \mathrm{Ni}$ and $\mathrm{Zn}$ have determined via ICP-OES by using microwave solubilisation system in vegetable samples from four different regions on which greenhouse and chemical fertilization process is not applied. The validity of the method is controlled with certified reference material (Tomato Leaves (NIST1573a). Recovery values have found over $95 \%$. Univariate ANOVA test is applied on experimental results. Since Sig. value is $\mathrm{p}>0.05$ and $\mathrm{F}<\mathrm{F}_{\mathrm{k}}$ for each vegetable samples, it is seen that group variants are homogenous and there is not a significant difference between the soils of the four region.
\end{abstract}

Keywords: Microwave digestion; heavy metal; vegetable sample; ICP OES. (C) 2017 ACG Publications. All rights reserved.

\section{Introduction}

A tillage technique which improves the biodiversity of the soil, protect the organic material of the soil and prevent the erosion is used for growing vegetable production [1]. Frequently consumed and fertilized food cause immune system disorder and increase on cancer susceptibility by weakening the cells. When these facts are considered heavy metal accumulation may be occurred as the result of the over fertilization of the vegetables [2].

The effect of the agriculture on environment is very important $[3,4]$. Agricultural lands are mostly treated with chemical fertilizers. This causes heavy metal contamination in the soil. Numerous consumers are started to prefer to use organically produced food because of pesticide residues. This has caused an increase on the popularity of the organic food [5-7]. Organic Agriculture is generally offered as a solution in order to decrease the effect of the agriculture on environment [8]. There are crop yield differences between organic and conventional systems [9, 10]. "Organic Agriculture" is appeared as an alternative to conventional agriculture [11]. Organic Agriculture is a kind of production which aims to establish missing natural balance again, to forbid use of synthetic chemical drugs and fertilizers, to protect the soil, to increase the resistance of the plants and to increase to amount as well as the quality of the product [12].

Due to organic agriculture, agricultural productivity, recovery on the biodiversity of the soil, a better environment and decrease in the ecological risk is occurred [13-15]. Organic Agriculture has

*Corresponding author: E-Mail: dundar@sakarya.edu.tr, Tel.:(+90) 264 - 29560 44, Fax: (+90) 264 - 2955950.

The article was published by Academy of Chemistry of Globe Publications www.acgpubs.org/jem (C) Published 03/31/2017 EISSN:1307-6175 DOI:http://doi.org/10.25135/jcm.4.17.02.031 
begun in the middle of the 1980s in Turkey and spread very fast [16]. The first organic agricultural products are dried grape and fig in our country [17]. There are many efforts to protect the agricultural biodiversity which is disappeared because of the effect of the modern agriculture. [18-20]. Organic agriculture is growing continuously in the world and now 1.8 million farmers applies organic agricultural techniques on more than 37 million hectare in 162 countries [21].

A trace element which is essential for the creatures creates toxic effect on the organism when exposed to over dose as the result of the pollution [22]. Trace metal contents in the soil have increased by the contribution of the industrial and agricultural operations. As the time passes by, heavy metals which have become a great risk may be taken by humans, animals and plant from environment via food [1]. Heavy metal contamination at the agricultural environment may be come by pesticide formulations, chemical fertilizers and contamination on weak quality water [23] and natural metal resources and production packaging processes can cause $\mathrm{Cu}, \mathrm{Fe}$ and $\mathrm{Zn}$ contamination [24-26].

The major contamination because of the fertilizer is the nitrate contamination in water [2728]. Unconsciously used nitrogen fertilizers cause nitrate contamination at vegetables [29]. Increase on the heavy metal amount because of the fertilization may effect human health negatively.

Microwave solubilisation technique which is used for laboratory application provides various advantages by dissolving samples rapidly [30-33]. Mineral analysis on vegetables is very wide and there are numerous techniques in the literature. Some of them are inductively coupled plasma optical emission spectrometry (ICP OES) or inductively coupled plasma mass spectrometry (ICP-MS) [25, $31]$.

ANOVA test which is used on the univariate analysis of the results essentially handles the factors used in the experiment or the total of the square of the result variables in order to determine the contribution of their interactions on the experiment and determines the total variances. And then makes possible the election of the most suitable factor/parameter by calculating the contribution percentage of the change [34].

This study is performed in four different regions of Sakarya; Erenler, Söğütlü, Karasu and Beşköprü for the determination of heavy metals such as $\mathrm{Cu}, \mathrm{Fe}, \mathrm{Mn}, \mathrm{Ni}$ and $\mathrm{Zn}$ is performed by using ICP-OES via the microwave solubilisation technique of the samples of tomato, pepper, hot pepper, pepper sauce, cucumber, runner beans, aubergine, corn, potato and carrot on which chemical fertilization is not applied and grown in greenhouse. In order to determine if there is significant difference between four different region univariate ANOVA test is applied.

\section{Experimental}

\subsection{Instrument}

$\mathrm{Cu}, \mathrm{Fe}, \mathrm{Mn}, \mathrm{Ni}$ and $\mathrm{Zn}$ concentrations of the heavy metals which are examined in this study are measured with SPECTRO ARCOS model ICP-OES. Ultra-pure water, analytical grade $\mathrm{H}_{2} \mathrm{O}_{2}$ and $\mathrm{HNO}_{3}$ and NIST 1573a Tomato Leaves Multi standard solutions are used in the analysis. The operating parameters of determination of elements by ICP-OES: Viewingheight $12 \mathrm{~mm}$; Wavelength: Cu: $324.754 \mathrm{~nm}, \mathrm{Fe}: 238.204 \mathrm{~nm}, \mathrm{Mn}: 257.611 \mathrm{~nm}, \mathrm{Ni}: 231.604 \mathrm{~nm}, \mathrm{Zn}: 213.856 \mathrm{~nm}$; RF Power: 1450 W, Plasma Gas Flow: 18.0 L/min.; Auxiliary Gas Flow: 1.5 L/min.; Sample Pump Rate: 25 rpm.

\subsection{Reagent and solutions}

In order to prepare the solutions in the experimental study distilled deionized water (Milli-Q Millipore $18.2 \mathrm{M} \Omega \mathrm{cm}$ resistance) is used. Suprapur ${ }^{\circledR}$ nitric acid $(65 \%, \mathrm{w} / \mathrm{w})$ and analytical grade hydrogen peroxide (30\%, w/w) were purchased from Merck (Germany). All plastic and glass materials are remained in $\% 10 \mathrm{v} / \mathrm{v} \mathrm{HNO}_{3}$ solutions for a night and then washed with ultra-pure water. An ICP multi-element standard solution of $1000 \mathrm{mg} \mathrm{L}^{-1}$ (Merck), as the calibration standard, was diluted to the desired concentrations using ultra-distilled water with ICP-OES are prepared between $0.08-4 \mathrm{mg} / \mathrm{L}$ ranges. The accuracy of the proposed method was evaluated by analzying certified reference materials of SRM 1573a Tomato (National Institute of Standards and Technology, Gaithersbur, MD, USA). 


\subsection{Microwave Digestion of Samples}

Vegetable samples are washed with tap water and ultra-pure water before starting analysis. Then the samples are dried in the oven at $65{ }^{\circ} \mathrm{C}$ for 48 hours and pounded in the porcelain mortar. Approximately $1.0 \mathrm{~g}$ of the vegetable samples and $0.3 \mathrm{~g}$ of the reference material are digested with 7 $\mathrm{mL} \mathrm{HNO}_{3}(65 \%)$ and $1 \mathrm{~mL} \mathrm{H}_{2} \mathrm{O}_{2}(30 \%)$ in microwave system in order to solubilize the pulverized vegetable samples. Digestion program is set $5 \mathrm{~min}$ for $90{ }^{\circ} \mathrm{C}, 4 \mathrm{~min}$ for $90{ }^{\circ} \mathrm{C}, 5 \mathrm{~min}$ for $180{ }^{\circ} \mathrm{C}, 16$ min for $180^{\circ} \mathrm{C}$, ventilation: $8 \mathrm{~min}$, respectively.

\section{Results and discussion}

\subsection{Analysis of Reference Materials}

This method is validated with NIST 1573a Tomato Leaves. Standard reference material is digested with approximately $0.30 \mathrm{~g}$ of $7 \mathrm{~mL} \mathrm{HNO}_{3}(65 \%)$ and $1 \mathrm{~mL} \mathrm{H}_{2} \mathrm{O}_{2}(30 \%)$ in microwave system and recovery values for $\mathrm{Cu}, \mathrm{Fe}, \mathrm{Mn}, \mathrm{Ni}$ and $\mathrm{Zn}$ are calculated over $95 \%$. Results are given in Table 1 .

\begin{tabular}{cccc}
\hline Element & $\begin{array}{c}\text { Certified value } \\
(\mathbf{m g} / \mathbf{k g})\end{array}$ & Microwave & \% Recovery \\
\hline $\mathrm{Cd}$ & $1.52 \pm 0.04$ & $1.48 \pm 0.03$ & 97.4 \\
$\mathrm{Cu}$ & $4.70 \pm 0.14$ & $4.50 \pm 0.08$ & 95.7 \\
$\mathrm{Fe}$ & $368 \pm 7$ & $350 \pm 5$ & 95.1 \\
$\mathrm{Mn}$ & $246 \pm 8$ & $235 \pm 4$ & 95.5 \\
$\mathrm{Ni}$ & $1.59 \pm 0.07$ & $1.52 \pm 0.03$ & 95.6 \\
$\mathrm{Zn}$ & $30.9 \pm 0.7$ & $30.5 \pm 0.2$ & 97.4 \\
\hline
\end{tabular}

Table 1. The results for certificated standart materials $(\mathrm{N}=3)$ and $\%$ recovery values 
Table 2. The result of the heavy metal determination in a dried greenhouse vegetables $\left(\mu \mathrm{g} \mathrm{g}^{-1}\right)$. (average \pm S.D., $\mathrm{N}=3$ ) N.D: not detected

As it can be seen in the table to the values gathered by the experimental data cohere with the certified values. These results show the validity of the solubilisation via microwave method offered for the heavy metal analysis at the real samples. Recovery values which are calculated for each element is over $95 \%$. The result of the heavy metal determination in a dried greenhouse vegetables are given in Table 2.

Since Cd and Ni metal content are very low in the greenhouse vegetables it is not calculated according to the Table 2 . The highest metal content among the samples is corn with Fe $\left(28.91 \mu \mathrm{g} \mathrm{g}^{-1}\right)$ and the lowest is pepper with $\mathrm{Ni}\left(0.26 \mu \mathrm{g} \mathrm{g}^{-1}\right)$. The highest $\mathrm{Cu}$ amount is determined in hot pepper and the lowest is determined in runner beans. The highest Fe amount is determined in corn and the lowest is determined in carrot. The highest $\mathrm{Mn}$ amount is determined in corn and the lowest is determined in carrot. The highest Ni amount is determined in corn. The highest $\mathrm{Zn}$ amount is determined in runner beans and the lowest is determined in potato. When compared to vegetables which chemical fertilizer is not applied generally heavy metal levels are calculated highly.

Heavy metal content in the dried vegetables in four different regions is given in Table 3.

\subsection{ANOVA Test Results}

Since the single different factor is soil in the analysed samples ANOVA factor test is applied. sig. (significance (p)) value in the ANOVA table is examined. The group averages are measured with $F$ value if they are same or not. If $\mathrm{p}>0.05$ is bigger and $\mathrm{p}>0.05$, variances are distributed homogenously. Gathered results are given in Table 5. When you consider the $\mathrm{p}$ value in the table, the variance of the groups are homogenous because $\mathrm{p}>0.05$.

Since $\mathrm{Cd}$ and Ni metal contents are quite low, it is not possible to calculate the values. The highest metal content in the samples is the $\mathrm{Zn}$ amount and the lowest is the $\mathrm{Cu}$ in the corn. The highest $\mathrm{Cu}$ amount is found in hot pepper and the lowest is found in aubergine. The highest Fe amount is determined in hot pepper and the lowest is determined in cucumber. The highest Mn amount is determined in pepper and the lowest is determined in cucumber. The highest $\mathrm{Zn}$ amount is determined in hot pepper and the lowest is determined in cherry tomato. Heavy metal content on which fertilizer is

\begin{tabular}{lccccc}
\hline \multirow{2}{*}{ Samples } & $\mathbf{C u}$ & $\mathbf{F e}$ & $\mathbf{M n}$ & $\mathbf{N i}$ & $\mathbf{Z n}$ \\
\cline { 2 - 6 } & $3.26 \pm 0.01$ & $8.19 \pm 0.03$ & $3.28 \pm 0.04$ & N.D & $7.66 \pm 0.07$ \\
\hline Saucepepper & $2.59 \pm 0.02$ & $8.78 \pm 0.03$ & $3.78 \pm 0.02$ & N.D & $9.42 \pm 1.16$ \\
Cherry tomato & $2.89 \pm 0.01$ & $28.91 \pm 3.32$ & $6.26 \pm 0.01$ & $2.78 \pm 0.02$ & $14.63 \pm 1.12$ \\
Corn & $2.49 \pm 0.07$ & $6.32 \pm 0.03$ & $4.12 \pm 0.02$ & N.D & $10.95 \pm 0.09$ \\
Cucumber & $4.29 \pm 0.02$ & $15.41 \pm 2.18$ & $4.43 \pm 0.03$ & N.D & $12.38 \pm 1.14$ \\
Aubergine & $0.84 \pm 0.04$ & $9.48 \pm 0.04$ & $2.57 \pm 0.07$ & N.D & $16.63 \pm 2.24$ \\
Runner beans & $5.09 \pm 0.02$ & $12.7 \pm 1.15$ & $4.57 \pm 0.02$ & $0.26 \pm 0.01$ & $13.37 \pm 1.09$ \\
Hot pepper & $4.47 \pm 0.06$ & $17.45 \pm 3.10$ & $4.70 \pm 0.11$ & N.D & $12.72 \pm 2.10$ \\
Pepper & $3.47 \pm 0.04$ & $8.29 \pm 0.07$ & $3.16 \pm 0.04$ & N.D & $16.46 \pm 3.19$ \\
Tomato & $0.97 \pm 0.01$ & $27.49 \pm 3.15$ & $2.52 \pm 0.02$ & $0.55 \pm 0.01$ & $6.20 \pm 0.20$ \\
Potato & $2.55 \pm 0.03$ & $7.94 \pm 1.12$ & $2.33 \pm 0.03$ & $1.05 \pm 0.02$ & $14.14 \pm 2.17$ \\
Carrot & & & & & \\
\hline
\end{tabular}


applied is calculated lower than the greenhouse vegetables. The lowest values for heavy metals are found at the vegetables in the Söğütlü region.

ANOVA test results are given in Table 4. $\mathrm{P}$ value is examined in the ANOVA test results and $p>0.05$ variance of the groups are accepted as homogenous. According to gathered data it is p $>0.05$ for each element in all regions. It provides information it $F$ averages same or not and it should be $\mathrm{F}<\mathrm{F}_{\mathrm{k}} . \mathrm{F}<\mathrm{F}_{\mathrm{k}}$ type and group averages are distributed homogenously. Since the variances distributed homogenously, it is seen that there is not a significant difference between soil samples.

\section{Conclusions}

Heavy metals such as $\mathrm{Cu}, \mathrm{Fe}, \mathrm{Mn}, \mathrm{Ni}$ and $\mathrm{Zn}$ in the vegetables on which greenhouse and chemical fertilization procedures are not applied. As the result of this heavy metal amount in the vegetables on which chemical fertilization procedures are not applied is calculated as low. The lowest heavy metal amount among these vegetables is the vegetables grown in Sögütlü and the lowest amounts are determined in carrot and aubergine. Highest heavy metal amount of $\mathrm{Zn}$ and lowest heavy metal amount of $\mathrm{Cu}$ are determined in corn.

Univariate ANOVA test is applied to vegetables gathered from four different regions. Because sig value of the $\mathrm{Cd}, \mathrm{Cu}, \mathrm{Fe}, \mathrm{Mn}, \mathrm{Ni}$ and $\mathrm{Zn}$ metals in the vegetables in each region is $\mathrm{p}>0.05$ and $\mathrm{F}<\mathrm{F}_{\mathrm{k}}$, zero hypothesis is accepted. The variances of the groups are homogenous with $95 \%$ reliability and there is not any significance between the soil samples of four different regions. It is seen that the difference between the samples in which chemical fertilization are not applied and greenhouse is not caused by the soil, there is heavy metal accumulation because of the fertilization. 
Table 3. Heavy metal content in the dried vegetables in four different regions $\left(\mu \mathrm{g} \mathrm{g}^{-1}\right)$. (average \pm S.D., $N=3$ )

\begin{tabular}{|c|c|c|c|c|c|c|c|c|c|c|c|c|c|c|c|c|c|c|c|c|}
\hline \multirow{2}{*}{ Samples } & \multicolumn{5}{|c|}{ Beşköprü vegetables } & \multicolumn{5}{|c|}{ Karasu vegetables } & \multicolumn{5}{|c|}{ Söğütlü vegetables } & \multicolumn{5}{|c|}{ Ereneler vegetables } \\
\hline & $\mathrm{Cu}$ & $\mathbf{F e}$ & Mn & $\mathbf{N i}$ & $\mathbf{Z n}$ & $\mathrm{Cu}$ & $\mathrm{Fe}$ & Mn & $\mathbf{N i}$ & $\mathbf{Z n}$ & $\mathrm{Cu}$ & $\mathrm{Fe}$ & Mn & $\mathrm{Ni}$ & $\mathbf{Z n}$ & $\mathbf{C u}$ & $\mathrm{Fe}$ & Mn & $\mathbf{N i}$ & $\mathbf{Z n}$ \\
\hline Saucepepper & $\begin{array}{l}3.17 \pm \\
0.09\end{array}$ & $10 \pm 1$ & $\begin{array}{c}3.39 \pm \\
0.03\end{array}$ & N.D & $\begin{array}{c}10.2 \pm \\
1.2\end{array}$ & & & & & & $\begin{array}{c}2.3 \pm \\
0.1\end{array}$ & $\begin{array}{c}6.64 \pm \\
0.02\end{array}$ & $\begin{array}{l}1.78 \pm \\
0.03\end{array}$ & ND & $\begin{array}{c}9.0 \pm \\
1.1\end{array}$ & & & & & \\
\hline Cherrytomato & $\begin{array}{c}1.98 \pm \\
0.01\end{array}$ & $\begin{array}{c}5.58 \pm \\
0.04\end{array}$ & $\begin{array}{c}2.61 \pm \\
0.01\end{array}$ & N.D & $\begin{array}{c}5.89 \pm \\
0.07\end{array}$ & & & & & & & & & & & $\begin{array}{c}1.58 \\
\pm \\
0.01\end{array}$ & $\begin{array}{c}6.42 \pm \\
0.02\end{array}$ & $\begin{array}{c}1.69 \pm \\
0.03\end{array}$ & $\mathrm{ND}$ & $\begin{array}{c}9.1 \pm \\
0.4\end{array}$ \\
\hline Corn & & & & & & $\begin{array}{c}0.88 \pm \\
0.02\end{array}$ & $\begin{array}{c}10.45 \\
\pm \\
0.09\end{array}$ & $\begin{array}{l}3.34 \pm \\
0.03\end{array}$ & ND & $\begin{array}{c}19.2 \pm \\
2.3\end{array}$ & & & & & & & & & & \\
\hline Cucumber & $\begin{array}{c}3.13 \pm \\
0.03\end{array}$ & $\begin{array}{c}6.93 \pm \\
0.08\end{array}$ & $\begin{array}{c}2.73 \pm \\
0.04\end{array}$ & N.D & $\begin{array}{c}15.22 \pm \\
1.71\end{array}$ & $\begin{array}{c}2.97 \pm \\
0.02\end{array}$ & $\begin{array}{c}7.57 \pm \\
0.04\end{array}$ & $\begin{array}{c}3.02 \pm \\
0.01\end{array}$ & ND & $\begin{array}{l}10.97 \\
\pm 0.06\end{array}$ & $\begin{array}{l}2.48 \pm \\
0.03\end{array}$ & $\begin{array}{c}8.19 \pm \\
0.04\end{array}$ & $\begin{array}{c}2.13 \pm \\
0.03\end{array}$ & ND & $\begin{array}{c}9.93 \pm \\
003\end{array}$ & ND & $\begin{array}{c}1.84 \pm \\
0.03\end{array}$ & $\begin{array}{c}5.88 \pm \\
0.04\end{array}$ & $\mathrm{ND}$ & $\begin{array}{c}9.33 \pm 0 . \\
04\end{array}$ \\
\hline Aubergine & $\begin{array}{c}2.5 \pm \\
0.2\end{array}$ & $\begin{array}{c}8.48 \pm \\
0.41\end{array}$ & $\begin{array}{c}3.7 \pm \\
0.3\end{array}$ & N.D & $\begin{array}{c}15.82 \pm \\
1.54\end{array}$ & $\begin{array}{c}1.71 \pm \\
0.02\end{array}$ & $\begin{array}{c}7.4 \pm \\
0.4\end{array}$ & $\begin{array}{c}2.7 \pm \\
0.1\end{array}$ & ND & $\begin{array}{c}9.33 \pm \\
0.09\end{array}$ & $\begin{array}{c}0.74 \pm \\
0.02\end{array}$ & $\begin{array}{c}3.55 \pm \\
0.02\end{array}$ & $\begin{array}{c}1.77 \pm \\
0.03\end{array}$ & ND & $\begin{array}{c}7.54 \pm \\
0.06\end{array}$ & & & & & \\
\hline Runner beans & & & & & & $1.57 \pm$ & $\begin{array}{c}13.37 \\
\pm \\
0.09\end{array}$ & $\begin{array}{c}4.16 \pm \\
0.03\end{array}$ & ND & $\begin{array}{c}12.85 \\
\pm \\
0.01\end{array}$ & & & & & & & & & & \\
\hline Hot pepper & $\begin{array}{c}5.86 \pm \\
0.03\end{array}$ & $\begin{array}{c}11.74 \\
\pm \\
0.08\end{array}$ & $\begin{array}{l}4.17 \pm \\
0.02\end{array}$ & N.D & $\begin{array}{c}16.41 \pm \\
2.12\end{array}$ & $\begin{array}{c}3.33 \pm \\
0.01\end{array}$ & $\begin{array}{c}10.96 \\
\pm \\
0.06\end{array}$ & $\begin{array}{c}3.25 \pm \\
0.02\end{array}$ & ND & $\begin{array}{c}9.25 \pm \\
0.06\end{array}$ & $\begin{array}{c}2.04 \pm \\
0.01\end{array}$ & $\begin{array}{c}7.06 \pm \\
0.06\end{array}$ & $\begin{array}{c}2.11 \pm \\
0.02\end{array}$ & ND & $\begin{array}{c}7.68 \pm \\
0.04\end{array}$ & & & & & \\
\hline Pepper & & & & & & & & & & & & & & & & $\begin{array}{c}3.25 \\
\pm \\
0.03\end{array}$ & $\begin{array}{c}17.58 \\
\pm \\
1.13\end{array}$ & $\begin{array}{c}5.08 \pm \\
0.03\end{array}$ & ND & $\begin{array}{c}11.83 \pm \\
1.10\end{array}$ \\
\hline Tomato & & & & & & $\begin{array}{c}1.92 \pm \\
0.02\end{array}$ & $\begin{array}{c}7.62 \pm \\
0.03\end{array}$ & $\begin{array}{c}2.37 \pm \\
0.01\end{array}$ & ND & $\begin{array}{c}8.04 \pm \\
0.06\end{array}$ & $\begin{array}{c}2.75 \pm \\
0.04\end{array}$ & $\begin{array}{l}7.18 \pm \\
0.09\end{array}$ & $\begin{array}{c}2.16 \pm \\
0.02\end{array}$ & ND & $\begin{array}{c}7.93 \pm \\
0.01\end{array}$ & $\begin{array}{l}3.48 \\
\pm 01\end{array}$ & $\begin{array}{c}6.13 \pm \\
0.02\end{array}$ & $\begin{array}{c}1.75 \pm \\
0.02\end{array}$ & $\mathrm{ND}$ & $\begin{array}{c}11.83 \pm \\
0.07\end{array}$ \\
\hline Carrot & & & & & & & & & & & & & & & & $\begin{array}{c}1.75 \\
\pm \\
0.10\end{array}$ & $\begin{array}{c}3.77 \\
\pm 0.01\end{array}$ & $\begin{array}{c}1.21 \\
\pm 0.20 \\
\end{array}$ & N.D & $\begin{array}{c}7.88 \\
\pm 0.04\end{array}$ \\
\hline
\end{tabular}

N.D: (Not Detected) 
Table 4. Univariate ANOVA test results in vegetables. Greenhouse vegetables

Söğütlü vegetables

\begin{tabular}{|c|c|c|c|c|c|c|c|c|c|c|c|c|c|c|c|}
\hline Elements & P-value & $\mathbf{F}$ & $\begin{array}{c}F \\
\text { factor }\end{array}$ & P-value & $\mathbf{F}$ & $\begin{array}{c}F \\
\text { factor }\end{array}$ & P-value & $\mathbf{F}$ & $\begin{array}{c}F \\
\text { factor }\end{array}$ & P-value & $\mathbf{F}$ & $\begin{array}{c}F \\
\text { factor }\end{array}$ & P-value & $\mathbf{F}$ & $\begin{array}{c}F \\
\text { factor }\end{array}$ \\
\hline $\mathrm{Cu}$ & 0.999 & 0.004 & 3.354 & 0.990 & 0.009 & 4.256 & 0.999 & 0.0008 & 3.885 & 0.974 & 0.0263 & 3.682 & 0.979 & 0,020 & 3,885 \\
\hline $\mathrm{Fe}$ & 0.391 & 0.971 & 3,354 & 0.969 & 0.001 & 4.256 & 0.998 & 0.0018 & 3.885 & 0.980 & 0.01978 & 3.682 & 0.977 & 0,023 & 3,885 \\
\hline Mn & 0.998 & 0.001 & 3.354 & 0.967 & 0.033 & 4.256 & 0.968 & 0.0323 & 3.885 & 0.993 & 0.0068 & 3.682 & 0.861 & 0,151 & 3,885 \\
\hline $\mathbf{N i}$ & 0.990 & 0.009 & 3.354 & - & - & - & - & & - & - & & - & - & - & - \\
\hline Zn & 0.999 & 0.000 & 4.255 & 0.975 & 0.024 & 4.256 & 0.986 & 0.0131 & 3.885 & 0.914 & 0.09038 & 3.682 & 0.598 & 0,535 & 3,885 \\
\hline
\end{tabular}




\section{References}

[1] M. Zeeb, M.R. Ganjali, P. Norouzl and M.R. Kalaee (2011). Separation and preconcentration system based on microextraction with ionic liquid for determination of copper in water and food samples by stopped-flow injection spectrofluorimetry, Food Chem. Toxicol 49,1086-1091.

[2] A. Yılmaz (2011). Organic Agriculture in Turkey. Karadeniz Teknik Üniversitesi, Sosyal Bilimler Enstitüsü İktisat Bölümü, Yüksek Lisans Tezi, Trabzon.

[3 ] J.A. Foley, R. Defries, G.P. Asner, C. Barford, G. Bonan, S.R. Carpenter, F.S. Chapin, M.T. Coe, G.C. Daily, H.K. Gibbs, J.H. Helkowski, T. Holloway, E.A. Howard, C.J. Kucharik, C. Monfreda, J.A. Patz, I.C. Prentice, N. Ramankutty and P.K. Snyder (2005). Global consequences of landuse, Science 309,570-574.

[4] J.A. Foley, N. Ramankutty, A. Brauman, E.S. Cassidy, J.S. Gerber, M. Johnston, N.D. Mueller, C. Connell, D.K. Ray, P.C. West, C. Balzer, E.M. Bennett, S.R. Carpenter, J. Hill, C. Monfreda, S. Polasky, J. Rockstrom, J. Sheehan, S. Siebert, D. Tilman and D.P.M. Zaks (2011). Solutions for a cultivated planet, Nature 478, 337-342.

[5] I. Belicke and M. Bleidere (2005). Variety testing for organic farming: current status and problems in Europe. Seminar. 6th Framework programme. Envirofood web paper, [Accessed December 2006].

[6] N. Shauer, D. Zamir and R. Fernie (2005). Metabolic profiling of leaves and fruit of wild species tomato: a survey of the Solanum lycopersicum complex, J. Exp. Bot 56,197-307.

[7] N. Andreal, I. Giordano, A. Pentangelo, V. Fogliano, G. Graziani, L.M. Monti and R. Rao (2004). DNA fingerprinting and quality traits of Corbarino cherry-like tomato landraces, J. Agr. Food Chem. 52, 3366-3371.

[8] V. Seufert, N. Ramankutty and J.A. Foley 2012b (2012). The yield performance of organic agriculture. In: Corson, M.S., van der Werf, H.M.G. (Eds.), 8th International Conference on Life Cycle Assessment in the Agri-food Sector (LCA Food 2012), 1-4 October. INRA, Rennes, France, Sain-Malo, France, 3136

[9] T. de Ponti, B. Rijk and M.K. van Ittersum (2012). The crop yield gap between organic and conventional agriculture, Agr. Syst. 108, 1-9.

[10] V. Seufert, N. Ramankutty and J.A. Foely (2012). Comparing the yields of organic and conventional agriculture, Nature 485, 229-232.

[11] A. Altındişli and E. İlter (1999). Ecological agriculture training course notes, 24-29.

[12] N.K. Fagerı, V.C. Balıgar and R.B. Clark (2002). Micronutrients in crop production, Adv. Agron. 77, 185-268.

[13] R.V. Misra, R.N. Roy and H. Hiraoka (2003). On farm composting methods Land and Water Discussion Paper 2. Food and Agriculture Organization of the United Nations, Rome.

[14] R. Paradelo, A.B. Moldes and M.T. Barral (2013). Evolution of organic matter during the mesophilic composting of lignocellulosic winery wastes, J. Environ Manage 116, 18-26.

[15] L. Roca-Pérez, C. Martínez, P. Marcilla and R. Boluda (2009). Composting rice straw with sewage sludge and compost effects on the soil-plant system, Chemosphere 75, 781-787.

[16] H. Taşbaşl1 (2003). Organic Agriculture in Turkey. Biodiversity and organic farming workshop in Turkey, 15-16 April, Ankara.

[17] M.A. Marangoz, M. Tunay, S. Karakis and A. Atesoglu (2007). Detecting urban vegetation from different images using an object-based approach in Bartin, Turkey, 636-640.

[18] N.E. Scialabba (2003). Organic farming: the maintenance of biodiversity enriching food production. Biodiversity and organic farming workshop in, 15-16 April, Ankara

[19] I. Duman, E. Düzyaman, D. Esiyok, H. Vural and S. Erkan (2005). Improving productivity of openpollinated processing tomato cultivars, Hortic Sci. 40,1682-1685.

[20] E. Düzyaman, I. Duman, M. Gümüş, D. Esiyok and H. Vural (2006). Possibilities of genetic reimprovement in open pollinated processing tomato cultivars, a case study from Turkey, Eur. J. Hortic Sci. 71(5), 199-206.

[21] H. Willer and L. Kilcher (2013). The World of Organic Agriculture: Statistics and Emerging Trends, Frick, Switzerland: Research Institute of Organic Agriculture (FiBL) \& Bonn. International Federation of Organic Agriculture Movements (IFOAM), Rheinbreitbanch, Germany.

[22] N. Ozcan and H. Altundag (2013). Speciation of heavy metals in street dust samples from Sakarya I. Organized Industrial District using the bcr sequential extraction procedure by ICP-OES, Bull. Chem. Soc. Ethiop. 27, 205-212.

[23] J.E. Marcovecchio, S.E. Botté and R.H. Freije (2007). Heavy metals, major metals, trace elements. In L. M. L. Nollet (Ed.), Boca Raton: CRC Press, Handbook of water analysis, 275-311. 
[24] D. Mendil, O.D. Uluozlu, M. Tüzen and M. Soylak (2009). Investigation of the contents of some element in edible oil samples produced in Turkey by atomic absorption spectrometry, J. Hazard Mater. 165, 724-728.

[25] M. Zeiner, I. Steffan and I.J. Cindric (2005). Determination of trace elements in oliveoil by ICP AES and ETA-AAS, a pilot study on the geographical characterization, Microchem J. 81, 171-176.

[26] C. Benincasa, J. Lewis, E. Perri, G. Sindona and A. Tagarelli (2007). Determination of trace element in Italian virgin olive oils and their characterization according to geographical origin by statistical analysis, Anal. Chim. Acta. 585, 366-370.

[27] B. J. Andraski, E.A. Jacobson (2000). Testing a full-range soil-water retention function in modeling water potential and temperature, Water Resour Res. 36(10), 3081-308.

[28] E. Karnez, K. Korkmaz, H. Ibrikci, G. Buyuk, J. Ryan, H. Oguz and A.C. Ulger (2010). Responses of wheat genotypes to phosphorus fertilization under rainfed conditions in the Mediterranean region of Turkey, Scientific research and essays 5(16), 2304-2311.

[29] F. Fidan, C. Genc and G. Simsek (1994). Some of salads of different nitrogen doses on nitrate accumulation and to investigate the effect of the growing period. Atatürk Central Horticultural Research Institute, Yalova.

[30] A. Angioni, M. Cabitza, M.T. Russo and P. Caboni (2006). Influence of olive cultivars and period of harvest on the contents of $\mathrm{Cu}, \mathrm{Cd}, \mathrm{Pb}$, and $\mathrm{Zn}$ in virgin olive oils, Food Chem. 99, 525-529.

[31] Y. Sahan, E.F. Basog and S. Gücer (2007). ICP-MS analysis of a series of metals (Mg, Cr, Co, Ni, Fe, $\mathrm{Cu}, \mathrm{Zn}, \mathrm{Sn}, \mathrm{Cd}$ and $\mathrm{Pb}$ ) in black and gren olive samples from Bursa, Turkey, Food Chem. 105, 395-399.

[32] R. Ansari, T.G. Kazi, M.K. Jamali, M.B. Arain, M.D. Wagan, N. Jalbani, H.I. Afridi and A.Q. Shah (2009). Variation in accumulation of heavy metals in different verities of sunflower seed oil with the aid of multivariate technique, Food Chem. 115, 318-323.

[33] L.S. Nunes, J.T.P. Barbosa, A.P. Fernandes, V.A. Lemos, W.N.L. Dossantos, M.G.A. Korn and L.S.G. Teixeira (2011). Multi-element determination of $\mathrm{Cu}, \mathrm{Fe}, \mathrm{Ni}$ and $\mathrm{Zn}$ content in vegetable oils samples by high resolution continuum source atomic absorption spectrometry and micro emulsion sample preparation, Food Chem. 127, 780-783.

[34] I. Gencel (2007). Very Additive Using the Taguchi Method and Alcohol Problems in the Optimization of an application in the industry, Master Thesis, Kocaeli University, Institute of Science and Technology, Kocaeli. 29-30.

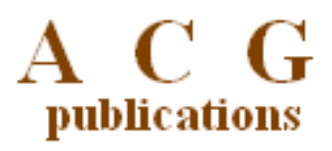

(C) 2017 ACG Publications. 